\title{
DNA HAEMAGGLUTINATION TEST IN THE DIAGNOSIS OF SYSTEMIC LUPUS ERYTHEMATOSUS
}

\author{
BY \\ E. J. JOKINEN* AND H. JULKUNEN \\ From the Department of Serology and Bacteriology and the Second Medical Clinic, \\ University of Helsinki, and the Maria Hospital, Helsinki, Finland
}

The occurrence of deoxyribonucleic acid (DNA) antibodies in the sera of patients with systemic lupus erythematosus (SLE) has been established by several authors by different techniques. Their diagnostic value has been studied in more extensive series of patients by Jokinen and Mäkitalo (1960: passive haemagglutination and complement-fixation), Kayhoe, Nasou, and Bozicevich (1960: bentonite flocculation), Rothfield, Phythyon, McEwen and Miescher (1961: conglutinin-complement-fixation), and Seligmann (1963: precipitation, complementfixation, and bentonite flocculation).

Lawlis (1958) described a passive haemagglutination method using formalinized erythrocytes sensitized with DNA. This method was used in diagnosis by Oliveira Lima, Fraga and Seabra (1961) and Lachmann (1964). Using the same method it is the aim of the present paper to throw light on the clinical significance of the occurrence of DNA antibodies within an extensive and diversified series of hospital patients.

\section{Material}

The series comprises 1,080 patients from the Second Medical Clinic, Helsinki University Central Hospital, where patients from all over Finland report for treatment, and the Medical Department, Maria Hospital, which receives patients domiciled in Helsinki. Independently of the authors, the physicians in charge of the patients had DNA antibody tests made for differential diagnosis. SLE was diagnosed in 63 of the patients by the physician in charge of the case at the time, and the patients were also seen by the authors. Nearly all these patients had been hospitalized more than once, and most of them had been followed clinically for several years. The diagnosis of SLE was based primarily on the clinical picture, L.E.-cell test, and positive biopsy. The most significant clinical and laboratory findings are given in Table I (overleaf), and the distribution of patients by disease

* This work was supported by grants from the Finnish Medical Research Council and the Sigrid Jusélius Foundation. activity and by corticosteroid treatment in Table II (overleaf).

Those patients were regarded as untreated who had received no corticosteroids for at least one month before the DNA haemagglutination test.

The 1,017 patients other than those with SLE are shown in Table IV (overleaf), which gives the diagnosis regarded as most important in each case.

\section{Method}

The passive haemagglutination method using DNA coupled to formalinized erythrocytes (Lawlis, 1958) was used with slight modifications.

\section{Reagents}

Phosphate-salıne: sodium chloride, 0.145 M, containing $0.005 \mathrm{M}$ sodium phosphate with final $\mathrm{pH}$ of $7 \cdot 3-7 \cdot 4$.

Formalin-saline: formaldehyde, $10 \mathrm{~g} . / 100 \mathrm{ml}$., in phosphate-saline with final $p \mathrm{H}$ of 7.0.

Coupling solution: McIlvaine's buffers mixed with $0 \cdot 145 \mathrm{M}$ saline, $p \mathrm{H} \mathrm{4.9}$

A highly polymerized commercial DNA (Mann Research Laboratories Inc., New York 6, N.Y.) was used as antigen.

Formalinization of Erythrocytes.-Human type $\mathrm{O}$ cells were washed three times with phosphate-saline, made to a 50 per cent. suspension, and chilled to $3^{\circ} \mathrm{C}$. This suspension was poured into four volumes of formalinsaline and stored at $3^{\circ} \mathrm{C}$. for at least 2 weeks with daily resuspension for the first week.

Coupling Technique.-Formalinized erythrocytes were washed five times in phosphate-saline. A 10 per cent. suspension of erythrocytes was made in the coupling solution containing DNA $0 \cdot 1 \mathrm{mg} . / \mathrm{ml}$. This was allowed to dissolve overnight before coupling in a $37^{\circ} \mathrm{C}$. water bath. This mixture was incubated in the water bath with mixing every $30 \mathrm{~min}$. for $4 \mathrm{hrs}$. Erythrocytes were then washed three times with phosphate-saline and made up to a 1 per cent. suspension in phosphate-saline.

Agglutination Test.-The sera to be tested were diluted $1: 4,1: 8$, etc., in phosphate-saline containing $1: 100$ normal rabbit serum in test tubes of $10 \mathrm{~mm}$. diameter. Each 
tube contained $0.5 \mathrm{ml}$. serum dilution, to which $0.1 \mathrm{ml}$. cell suspension was added. Formalinized but uncoupled cells were used as controls. The result was read after 4 to $5 \mathrm{hrs}$ and the end-point was taken as the highest serum dilution giving an even coating of cells over the bottom of the tube. Sera giving agglutination were re-tested after absorption with formalinized erythrocytes. A positive control serum with known titre was included in each series. The sera giving agglutination in a dilution of $1: 8$ or more were regarded as positive.

\section{Results}

The chief results are shown in Tables I, II, III, and IV. DNA antibodies were detected in nineteen (31 per cent.) of the 63 SLE patients. The highest positive titre in the series was $1: 512$. In addition to the findings presented in Table I, one patient with DNA antibodies had haemolytic anaemia and two showed biologically false positive tests for syphilis. Among the 44 patients without DNA antibodies two had malabsorption and three gave biologically false positive tests for syphilis.

TABLE I

MAIN CLINICAL AND LABORATORY DATA OF 63 SLE PATIENTS

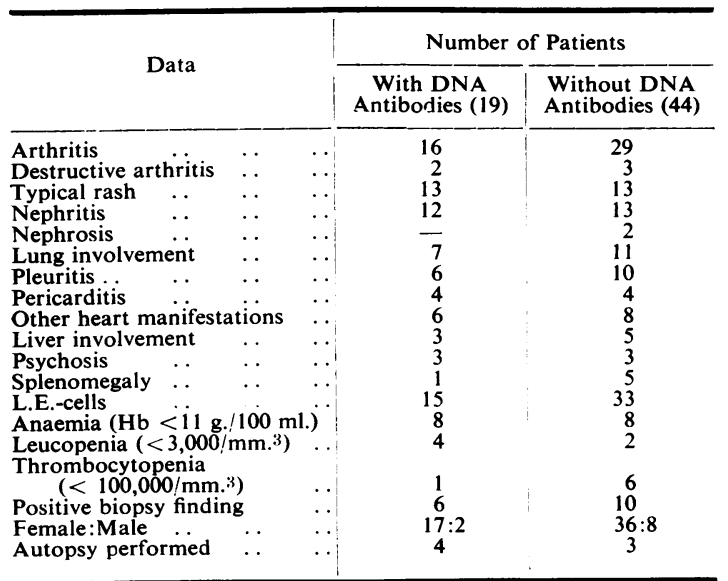

Table II shows the clear correlation between the occurrence of DNA antibodies and disease activity.
All but one of the positive cases had active SLE. Contrariwise in 33 of the 44 negative cases, the disease was in remission. A few patients with antibodies were followed up for over 6 months, and the antibodies disappeared or decreased in titre when the disease activity diminished whether spontaneously or after cortico-steroid treatment. Recrudescence of the disease was attended by reappearance of the antibodies.

In order to discover the primary symptomatic differences, if any, between the nineteen SLE patients with DNA antibodies and those without, the positive cases were compared with the 25 negative cases which had not been treated with corticosteroids (Table III). In patients with DNA antibodies the disease seems to have begun at a much earlier age and to have caused a greater number of organic manifestations.

TABLE III

COMPARISON OF SLE PATIENTS WITH AND WITHOUT DNA ANTIBODIES

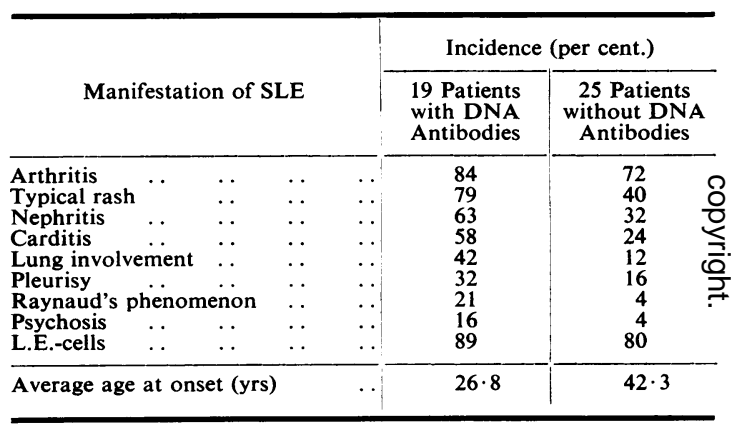

Of the 1,017 patients with diseases other than SLE, 231 suffered from "collagen diseases" and 786 from other ailments (Table IV, opposite). None of these patients had DNA antibodies.

\section{Discussion}

Data from the present series suggest that DNA antibodies occur only in cases of SLE. In considering the specificity of the results, the lowest titre regarded as positive is of course essential. In the authors' experience, a titre of $1: 8$ can be taken as

TABLE II

DISEASE ACTIVITY AND TREATMENT OF 63 SLE PATIENTS

\begin{tabular}{c|c|c}
\hline Disease Activity & Treatment & With DNA Antibodies \\
\hline Active & None \\
Corticosteroids & Wone \\
In Remission & Corticosteroids & 10 \\
\hline Total & & 0 \\
\hline
\end{tabular}


TABLE IV

1,017 PATIENTS WITH DISEASE OTHER THAN SLE DNA HAEMAGGLUTINATION TEST NEGATIVE

\begin{tabular}{|c|c|c|c|c|c|c|}
\hline & \multicolumn{4}{|l|}{ Disease } & \multicolumn{2}{|c|}{$\begin{array}{l}\text { Number } \\
\text { of Patients }\end{array}$} \\
\hline $\begin{array}{l}\text { Collagen } \\
\text { Diseases }\end{array}$ & $\begin{array}{l}\text { Rheumatoid arthritis } \\
\text { Rheumatoid spondylitis } \\
\text { Rheumatic fever . . } \\
\text { Polyarteritis nodosa } \\
\text { Dermatomyositis . . } \\
\text { Scleroderma } \quad \text {. } \\
\text { Non-defined collagen dise }\end{array}$ & $\begin{array}{l}\ldots \\
\cdots \\
\cdots \\
\cdots \\
\cdots \\
\text { ease }\end{array}$ & $\begin{array}{l}\cdots \\
\cdots \\
\cdots \\
\cdots \\
\cdots\end{array}$ & \begin{tabular}{l|}
$\cdots$ \\
$\cdots$ \\
$\cdots$ \\
$\cdots$ \\
$\cdots$ \\
$\cdots$
\end{tabular} & $\left.\begin{array}{r}156 \\
18 \\
29 \\
9 \\
3 \\
2 \\
14\end{array}\right\}$ & 231 \\
\hline $\begin{array}{c}\text { Other } \\
\text { Diseases }\end{array}$ & $\begin{array}{l}\text { Coronary or hypertensive } \\
\text { Carditis, or valvular hear } \\
\text { Erythema nodosum } \\
\text { Purpura . . } \\
\text { Raynaud's phenomenon } \\
\text { Renal disease* } \\
\text { Pulmonary disease } † \\
\text { Myeloma . . } \\
\text { Other neoplasms . } \\
\text { Haemolytic anaemia } \\
\text { Other blood diseases } \\
\text { Goitre, hyperthyroidism } \\
\text { Sarcoidosis } \\
\text { Malabsorption . . } \\
\text { Other gastro-intestinal di } \\
\text { Miscellaneous ... }\end{array}$ & $\begin{array}{l}\text { heart } \\
\text { rt disea } \\
\ldots \\
\ldots \\
\ldots \\
\ldots \\
\ldots \\
\ldots \\
\ldots \\
\cdots \\
\ldots \\
\text { iseases } \\
\ldots\end{array}$ & $\begin{array}{l}\text { disease } \\
\text { ase } \\
\ldots \\
\ldots \\
\ldots \\
\ldots \\
\ldots \\
\ldots \\
\ldots \\
\ldots \\
\ldots \\
\cdots \\
\ldots \\
\ldots\end{array}$ & \begin{tabular}{l|}
$\ldots$ \\
$\cdots$ \\
$\ldots$ \\
$\cdots$ \\
$\cdots$ \\
$\ldots$ \\
$\ldots$ \\
$\ldots$ \\
$\cdots$ \\
$\ldots$ \\
$\cdots$ \\
$\cdots$ \\
$\cdots$
\end{tabular} & $\left.\begin{array}{r}88 \\
38 \\
19 \\
17 \\
4 \\
128 \\
80 \\
13 \\
47 \\
16 \\
62 \\
34 \\
11 \\
16 \\
66 \\
147\end{array}\right)$ & 786 \\
\hline
\end{tabular}

* Nephritis, nephrosis, pyelonephritis

$\uparrow$ Tuberculosis, pleuritis, pneumonia, emphysema, bronchitis.

being definitely positive. Lower titres are apt to be due to an unspecific reaction, and were accordingly disregarded.

Slightly more non-specific results have been reported with the bentonite flocculation test. DNA antibodies in a low titre were found in one patient with rheumatoid arthritis and in another with scleroderma by Kayhoe and others (1960) in a series of 844 patients. Seligmann (1963) obtained a positive result in 5 per cent. of patients with rheumatoid arthritis, with positive L.E.-cells. Both with the complement-fixation test and by precipitation he detected DNA antibodies in 1.3 per cent. of patients with rheumatoid arthritis. The conglutinin-complement-fixation test gave a positive result in two out of 39 cases of rheumatoid arthritis in the series reported by Rothfield and others (1961).

The present results suggest that the occurrence of DNA antibodies in SLE is not particularly frequent, in that only nineteen out of 63 patients gave a positive reaction. The proportion might well have been higher had the negative group been examined repeatedly over a longer period. Moreover, nearly half the patients in the series had been treated with corticosteroids, which evidently reduced the number of positive cases.

As regards both specificity and sensitivity, the results given by passive haemagglutination with tanned erythrocytes differ from those obtained with other techniques (Jokinen and Mäkitalo, 1960).
It is quite possible, however, that this technique, described by Miescher and Strässle (1957), is based on the use of a DNA-containing protein as antigen. This is suggested by its adhesion to tannin and the high N/P ratio (Mäkitalo and Jokinen, 1958). The present authors have not obtained positive results with this technique and SLE sera using pure and highly polymerized DNA preparations as antigens.

Our present results show that the occurrence of DNA antibodies depends on disease activity, as was also shown by other techniques (Kayhoe and others, 1960; Seligmann, 1963). It is also possible that SLE with DNA antibodies may differ from SLE without DNA antibodies, as suggested by the earlier onset, the greater number of symptoms, and the more severe clinical course.

The DNA haemagglutination test appears to be useful in the differential diagnosis of SLE. The results are readily reproducible and highly specific. Rheumatoid arthritis has been found to be attended by antibodies to nucleoprotein, histone, and whole nucleus (Rothfield and others, 1961; Dörner, Enderlin, Spiegelberg, and Miescher, 1961; Thompson, 1962, Ward, Johnson, and Holborow, 1964); antibodies to nucleoprotein have been found in systemic scleroderma and dermatomyositis (Friou, 1958; Bardawil, Toy, Galins, and Bayles, 1958; Scalettar, Marcus, Simonton, and Muschel, 1960). Positive cell tests have been reported in all these diseases (Kievits, Goslings, Schuit, and Hijmans, 1956; Marmont, 1959; Rothfield and others, 1961).

\section{Summary}

Using a passive haemagglutination method with formalinized erythrocytes sensitized with DNA, a study was made of the sera of 1,080 hospital patients, of whom 63 were suffering from systemic lupus erythematosus. In nineteen out of these, DNA antibodies were found at some stage of the disease, but in the other 44 they were permanently lacking. In 231 patients with other "collagen diseases" and 786 with miscellaneous diseases no DNA antibodies were found.

The occurrence of DNA antibodies was unmistakably linked to the activity of the disease. They were detected in eighteen out of thirty active cases, but in only one of 37 cases in remission whether spontaneous or due to corticosteroid therapy. Furthermore, patients with DNA antibodies seemed to be characterized by earlier onset and more numerous symptoms.

\section{REFERENCES}

Bardawil, W. A., Toy, B. L., Galins, N., and Bayles, T. B. (1958). Amer. J. Path., 34, 607. 
Dörner, M., Enderlin, M., Spiegelberg, H., and Miescher, P. (1961). Dtsch. med. Wschr., 86, 378.

Friou, G. J. (1958). Ann. intern. Med., 49, 866.

Jokinen, E. J., and Mäkitalo, R. (1960). Acta rheum. scand., 6, 297.

Kayhoe, D. E., Nasou, J. P., and Bozicevich, J. (1960). New Engl. J. Med., 263, 5.

Kievits, J. H., Goslings, J., Schuit, H. R. E., and Hijmans, W. (1956). Ann. rheum. Dis., 15, 211.

Lachmann, P. J. (1964). In"Recent Advances in Clinical Pathology, Series IV”, ed. S. C. Dyke, p. 391. Churchill, London.

Lawlis, J. F. Jr. (1958). Proc. Soc. exp. Biol. (N.Y.), 98, 300.

Mäkitalo, R., and Jokinen, E. J. (1958). Ann. Med. exp. Fenn., 36, 309.

Marmont, A. (1959). In "Immunopathology: First International Symposium Basel, Seelisberg, 1958", ed. P. Grabar and P. Miescher, p. 489. Schwabe, Basel.

Miescher, P., and Strässle, R. (1957). Vox Sang. (Basel), n.s. 2, 283.

Oliveira Lima, A., Fraga, C., and Seabra, O. (1961). Hospital (Rio de J.), 60, 569.

Rothfield, N. F., Phythyon, J. M., McEwen, C., and Miescher, P. (1961). Arthr. and Rheum., 4, 223.

Scalettar, R., Marcus, D. M., Simonton, L. A., and Muschel, L. H. (1960). New Engl. J. Med., 263, 226.

Seligmann, M. (1963). Arthr. and Rheum., 6, 542.

Thompson, G. R. (1962). Univ. Mich. med. Bull., 28, 378.

Ward, D. J., Johnson, G. D., and Holborow, E. J. (1964). Ann. rheum. Dis., 23, 306.
Réaction d'hémagglutination à l'ADN dans le

diagnostic du lupus érythémateux disséminé

\section{RÉSUMÉ}

A l'aide de la méthode d'agglutination passive des érythrocytes formalinisés et sensibilisés à l'ADN, on étudia les sérums de 1.080 malades hospitalisés dont 63 furent atteint de lupus érythémateux disséminé. Chez 19 d'entre eux on trouva des anticorps contre l'ADN à une certaine période de la maladie, mais chez les autres 44 malades leur absence fut totale. Chez 231 malades atteints d'autres "maladies du collagène" et chez les 786 patients souffrant de différentes affections on ne trouva pas d'anticorps anti-ADN.

L'occurrence des anticorps anti-ADN était indubitablement liée à l'activité morbide. On les décéla en 18 sur 30 cas actifs, mais seulement en un sur 37 cas en rémission, spontanée ou due à la thérapie corticostéroide. De plus, les malades accusant des anticorps contre l'ADN semblaient se caractériser par un début plus précoce et par des symptômes plus nombreux que les autres.

\section{Reacción de hemaglutinación del ADN en el diagnóstico del lupus eritematoso diseminado}

\section{Sumario}

Sirviéndose del método de aglutinación pasiva de eritrocitos formalinizados y sensibilizados con el ADN, se estudiaron los sueros de 1.080 enfermos hospitalizados, 63 de los cuales sufrieron de lupus eritematoso diseminado. En 19 de estos anticuerpos contra el ADN fueron encontrados en uno de los períodos de la enfermedad, pero en los demás 44 enfermos su ausencia fué total. En 238 pacientes con otras "enfermedades del colàgeno" y ê los 786 con varias enfermedades el anticuerpo anti-ADN no fué encontrado.

La ocurrencia de los anticuerpos anti-ADN fue inequívocadamente ligada a la actividad morbosa. Estos anticuerpos fueron hallados en 18 de los 30 casos activos, pero sólo en uno de los 37 casos en remisión, tanto espontánea como córtico-terapéutica. Además, los enfermos que tuvieron el anticuerpo anti-ADN parecieron caracterizarse también por un comienzo más temprano y por síntomas más abundantes. 